\title{
PERANCANGAN SISTEM INFORMASI PERSEDIAAN BARANG MENGGUNAKAN MICROSOFT ACCESS
}

\author{
Muhammad Rizaluddin*1, Evayani*2 \\ ${ }^{1,2}$ Program Studi Akuntansi Fakultas Ekonomi dan Bisnis Universitas Syiah Kuala \\ e-mail: muhammadrizaluddin23@gmail.com ${ }^{* 1}$, eva_sahib@ yahoo.com ${ }^{* 2}$
}

\begin{abstract}
Inventory information system is something that is often heard in a company. A company that is engaged in trading of such distributions must be familiar with the inventory system. The use of manual recording has a negative impact on the company. Looking at company earnings and how many remaining items available manually require a long time. This research aims to design an inventory information system to help employees manage goods and find available items more easily so as to reduce mistakes made by employees. The system designed in this study uses Microsoft Access. This research uses descriptive qualitative method, data collection techniques in research conduct interviews, observation, and literature study conducted directly with the owner of the company. This research produces an application that can help control the inventory of goods more effectively and informally so that it can control the goods entering and leaving the company.
\end{abstract}

Keywords: Information System, Accounting Information System, Inventories, and Microsoft Access.

\section{Pendahuluan}

Perkembangan teknologi pada era global mengubah segala sesuatu menjadi digital telah memacu perusahaan untuk menggunakan teknologi sebagai salah satu media dalam menjalankan perusahaannya. Perusahaan kini berlomba-lomba untuk meningkatkan penggunaan teknologi sebagai media untuk dapat bertahan dengan para kompetitornya dan juga untuk bersaing. Dalam era globalisasi persaingan yang semakin tajam menyebabkan perusahaan diharuskan memiliki suatu kelebihan untuk bisa mempertahankan kelangsungan perusahaannya.

Penggunaan dan perkembangan teknologi informasi memiliki peran penting dalam proses bisnis yang terjadi. Kemajuan yang pesat baik dalam aspek manajemen maupun aspek teknologi mendorong terciptanya lingkungan industri maju serta membawa dampak pada peningkatan persaingan yang semakin ketat dan terus berkembang dari persaingan regional menjadi persaingan global. Dalam era digital ini hampir semua sektor bisnis telah melibatkan penggunaan teknologi dalam menjalankan semua proses ekonomi perusahaan. Penggunaan teknologi yang dirasakan membawa berbagai manfaat dalam penggunaanya, salah satunya sistem informasi, bahkan pada beberapa sektor industri sudah menjadi suatu keharusan dalam penggunaan sebuah sistem informasi. Penggunaan sistem informasi akan mempermudah perusahaan yang bertujuan utnuk penyaluran informasi lebih mudah dan akurat sehingga proses bisnis yang tidak diperlukan dapat ditanggalkan sehingga membuat proses bisnis lebih efisien.

Pengunaan sistem informasi juga dapat memberikan manfaat yang berkaitan langsung dengan akuntansi. Peranan akuntansi sebagai pemberi informasi dalam pengambilan keputusan semakin penting disadari oleh para pelaku usaha. Penggunaan sistem manual sedikit demi sedikit sudah mulai ditinggalkan. Ditemukannya teknologi informasi, dunia bisnis menjadi semakin dimudahkan dalam segala kegiatan atau aktivitas yang biasa dilakukan seperti kegiatan pengumpulan data, pemrosesan, pengolahan, serta pengendalian dan pengamanan data menjadi lebih mudah dilakukan dan hasil yang dicapai bisa cepat, tepat, dan akurat. Romney dan Steinbart (2012:24) berpendapat bahwa sistem informasi akuntansi dapat berfungsi untuk mengelola data untuk proses transaksi akuntansi yang biasa terjadi untuk memperoleh informasi akuntansi dan keuangan.

Kesimpulan yang dapat di ambil adalah sistem informasi akuntansi berkaitan dengan informasi 
akuntansi yang terjadi di dalam sebuah perusahaan. Dengan adanya sistem dalam perusahaan diharapkan dapat membantu dalam pengelolaan informasi yang akurat dan relevan. Sistem informasi persediaan adalah sebuah bagian dari sistem informasi akuntansi yang memberikan informasi terkait persediaan perusahaan.

Beberapa jenis perusahaan memerlukan persediaan dalam menjalankan aktivitasnya. Stice dan Skousen (2009) dalam Anwar \& Karamoy (2014:1296) menyatakan bahwa persediaan adalah aset tetap yang tersedia untuk dijual dalam aktivitas yang terjadi dalam perusahaan atau aset yang diproses secara langsung dan tidak langsung ke barang yang akan diproduksi dan kemudian akan dijual . Penerapan sistem informasi persediaan dapat bermanfaat bagi perusahaan dan manajemen dalam mengelola usahanya (Baramuli \& Pengemanan S). Penggunaan sistem informasi persediaan diharapkan dapat meminimalisir kejadian-kejadian yang tidak diinginkan seperti kecurangan, error dan lain-lain.

Dalam beberapa industri, persediaan menjadi hal yang sangat sensitif dikarenakan persediaan mengambil peran penting dalam berjalannya operasional perusahaan. Dari sekian banyak perusahaan yang keberlangsungannya melibatkan persediaan, perusahaan yang bergerak dibidang retail adalah perusahaan yang memerlukan persediaan dalam operasionalnya. Sistem yang dirancang pada penelitian ini adalah sistem yang menggunakan metode first in first out sehingga sistem yang dirancang dapat menerapkan metode persediaan yang ada pada akuntansi dan dapat digunakan dalam berbagai perusahaan, namun pada penelitian kali ini mengambil contoh jenis usaha yang bergerak dibidang penjualan pakaian seperti distro, beberapa usaha tersebut adalah distro Blacksheep dan Menssurfing. Pemilihan objek didasari dengan keadaan perusahaan yang belum menerapkan sistem yang tepat pada perusaaannya. Penerapan sistem persediaan pada distro Blacksheep belum menggunakan sistem yang terkomputerisasi sehingga menyebabkan adanya kesalahan pencatatan dan kehilangan barang pada distro ini sedangkan pada distro Menssurfing, dikarenakan tidak adanya sistem persediaan distro ini mendapat masalah mengenai pelaporan yang sulit diterapkan secara realtime (hasil wawancara dengan pemilik perusahaan). Distro adalah perusahaan yang bergerak dibidang industri pakaian. Persediaan pakaian menjadi hal yang paling diperhatikan oleh perusahaan ini. Dalam kegiatan operasionalnya, distro sering mendapatkan masalah terkait dengan persediaan yang ada. Hal yang paling sering terjadi adalah catatan mengenai persediaan yang kurang valid dan tidak bisa diinformasikan secara realtime dikarenakan tidak adanya sistem yang terkomputerisasi sehingga semua kegiatan siklus persediaan dikerjakan secara manual.

Tidak adanya sistem yang terkomputerisasi juga membuat karyawan-karyawan pada perusahaan mendapatkan celah untuk melakukan kecurangan. Kecurangan-kecurangan yang dapat terjadi seperti pencurian dan juga kesalahan pada manusia. Sistem manual yang dijalankan oleh perusahaan juga menyebabkan beberapa masalah, seperti pencatatan barang yang harus dilakukan satu persatu, pembuatan laporan menjadi lebih lama, dan sulitnya untuk mengawasi sisa persediaan barang. Sistem manual yang dijalankan dapat menghambat perusahaan dalam melakukan kegiatannya. Hal ini dapat terjadi jika tidak adanya sistem yang secara otomatis mengatur siklus persediaan. Salah satu hal yang paling krusial yang terjadi dalam perusahaan terkait dengan persediaan yang disebabkan oleh tidak adanya sistem otomatis adalah barang yang menghilang tanpa adanya informasi jelas. Pencatatan dengan cara manual juga seringkali menyebabkan kekeliruan dalam pencatatan stok barang atau tidak tercatatnya transaksi ke dalam buku transaksi harian. Dengan adanya hal ini maka tentunya akan mempengaruhi keakuratan informasi dalam mengetahui seberapa banyak stock persediaan barang dari beberapa jenis produk yang tersedia.

Salah satu aplikasi yang dapat digunakan dalam pengolahan database persediaan adalah Microsoft Access. Microsoft Access (disebut juga Access) adalah aplikasi yang digunakan untuk mengelola database yang dapat membantu pengguna untuk mengelola dan memanipulasi data menggunakan fasilitas yang ada. Aplikasi ini memiliki kelebihan lain dalam hal kemudahan operasi dan ketersediaan aplikasi dimasyarakat (Wulandari \& Nugroho, 2012).

Penggunaan perangkat lunak Microsoft Access selaku basis datanya diharapkan dapat dijadikan pertimbangan dalam memperbaiki proses pencatatan data barang sehingga dapat mempermudah kegiatan yang ada di dalam perusahaan. Penerapan Sistem Informasi Akuntansi (SIA) secara terkomputerisasi diharapkan akan memberikan dampak yang 
menguntungkan bagi perusahaan dan para karyawannya, yaitu sistem akuntansinya akan lebih mudah dan cepat sehingga dapat meminimalisir setiap kesalahan yang ada dalam menginput data dan mempercepat pengerjaan terhadap sistem informasi persediaan

Penelitian bertujuan untuk merancang suatu aplikasi berbasis Microsoft Access di Distro Blacksheep dan Menssurfing yang nantinya akan mengolah data terkait dengan siklus persediaan yang terjadi. Penerapan sistem informasi yang terkomputerisasi diharapkan akan memudahkan perkerjaan karyawan dan juga dapat mencegah terjadinya kecurangan atau kesalahan pada manusia.

Penelitian ini bertujuan untuk merancang suatu aplikasi berbasis Microsoft Access di Distro Blacksheep dan Menssurfing yang nantinya akan mengolah data terkait dengan siklus persediaan yang terjadi. Penerapan sistem informasi yang terkomputerisasi diharapkan akan memudahkan perkerjaan karyawan dan juga dapat mencegah terjadinya kecurangan atau kesalahan pada manusia.

\section{Kajian Teoritis dan PengembanganHipotesis Sistem}

Davis B. Gordon (2013:3)mengungkapkan sistem dapat berarti komponen atau bagian-bagian yang saling berhubungan yang saling beroperasi untuk mencapai sebuah tujuan. Menurut kutipan para ahli yang telah disampaikan maka dapat diambil kesimpulan bahwa sistem merupakan kumpulankumpulan dari beberapa komponen yan terbentuk dan berintegrasi untuk mencapai sebuah tujuan.

\section{Sistem Informasi}

\section{Menurut}

Ladjamudin

(2013:13) mendeskripsikan sistem informasi sebagai sekumpulan tahap kegiatan organisasi yang pada saat dijalankan akan memberikan informasi untuk pengambil keputusan dan untuk mengendalikan organisasi. Menurut Hartono (2013:9) sistem adalah suatu himpunan dari berbagai bagian atau elemen yang saling berhubungan secara terorganisasi berdasarkan fungsi-fungsinya, menjadi suatu kesatuan

\section{Sistem InformasiAkuntansi}

Menurut Krismiaji (2010:23) Sistem Informasi Akuntansi adalah suatu sistem yang berguna untuk memproses data dan transaksi menjadi informasi yang lebih berguna untuk merencanakan, mengendalikan, dan menjalankan sebuah bisnis. Sistem Informasi Akuntansi merupkan sebuah sistem yang mengumpulkan, mencatat, dan memproses data yang bertujuan untuk menghasilkan informasi yang lebih berguna untuk mengambil sebuah keputusan (Romney dan Steinbart, 2012:24).

\section{Persediaan}

Persediaan adalah barang tersedia untuk dijual untuk kegiatan usaha, dalam proses produksi untuk penjualan tersebut, atau dalam bentuk bahan baku atau perlengkapan untuk digunakan dalam proses produksi atau pemberian jasa (PSAK 14, 2008).

Sebelum melakukan penilaian persediaan maka penentuan jumlah persediaan perlu dilakukan. Jumlah persediaan dapat dilihat dengan dua sistem yang umum pada akhir periode yaitu periodik dan perpetual. Sistem periodik adalah melakukan penghitungan barang secara langsung agar sisa barang dapat diketahui secara pasti pada setiap akhir periode, sedangkan sistem perpetual adalah barang setiap kali ada transaksi yang dilakukan (S Warren et al., 2014). Menurut S Warren et al (2014) dalam melaksanakan pengendalian persediaan ada beberapa metode yang dapat dipergunakan yaitu:

1) Metode Fifo

2) Metode Lifo

3) Metode Average

\section{Microsoft Access}

Akbar (2013:41) menyatakan Microsoft access adalah sebuah software yang dapat mengolah database yang bisa beroperasi di dalam sistem windows. Microsoft access adalah salah satu dari sebuah produk yang dikembangkan oleh Microsoft, produk tersebut bernama Office. Dalam mengolah database, Access memiliki sarana yang dapat membantu pekerjaan pengguna. 


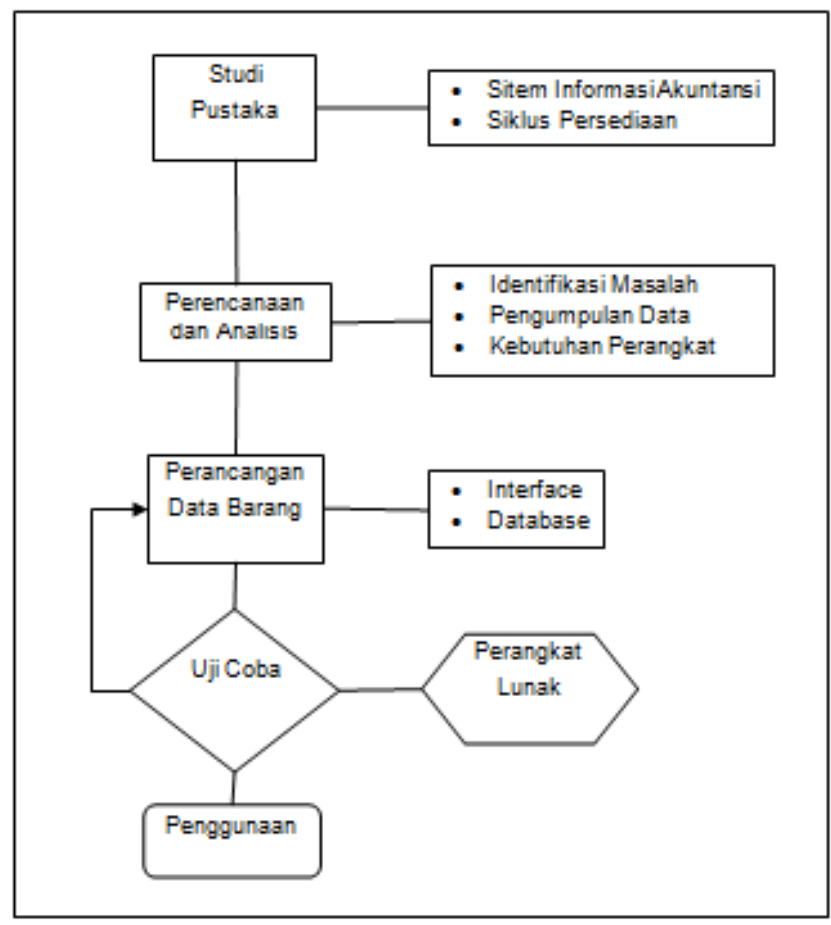

Gambar 1. Kerangka Pemikiran

\section{Metode Penelitian}

\section{Desain Penelitian}

Penelitian ini bertujuan untuk menguji hipotesis. Jenis investigasi pada penelitian ini menggunakan jenis penelitian studi koleraional dimana peneliti ingin mengetahui variable yang terkait maka studi korelasional yang akan dilakukan. Situasi penelitian ini adalah tidak diatur. Unit analisis dalam penelitian ini adalah perusahaan yang merupakan Distro Blacksheep dan MenSurfing. dan data yang dikumpulkan yaitu berupa data primer dan data sekunder. Penelitian ini bersifat studi longitudional.

\section{Sumber dan Teknik PengumpulanData}

Penelitian ini memili sumber data primer dan data sekunder. Wawancara dan pengamatan merupakan data primersedangkan data sekunder berupa data dokumentasi, seperti faktur penjualan. Pengumpulan data yang dilakukan dalam penelitian merupakan penelitian langsung yang turun ke lapangan dan studi kepustakaan.

\section{Proses Rencana Penelitian}

\section{Studi Pustaka}

Proses ini mengumpulkan data pustaka yang berfungsi untuk acuan teori dan berguna untuk menggambarkan sistem informasi persediaan barang.

\section{Perencanaan dan Analisis}

Pada proses ini peneliti mulai mengembangkan sistem informasi persediaan barang untuk Distro Balacksheep dan Menssurfing. Proses ini melakukan analisis sehingga menemukan masalah yang terjadi pada perusahaan. Belum adanya sistem persediaan barang pada distro Blacksheep dan Mensurfing menjadi salah satu masalah yang terjadi, belum tersedianya basis data pada perusahaan sehingga sulit untuk menyimpan, mengolah, dan menampilkan data secara akurat dan tepat.

\section{Perancangan}

Pada proses ini merancang sebuah konsep diagram alir data dan diagram konteks. Kemudain elamkukan perancangan fisik yang berupa perancangan output. Perancangan ini akan menentukan format dan isi laporan yang dihasilkan.

\section{Pengujian}

Setelah sistem selesai dirancang, maka tahap berikutnya yaitu tahap pengujian. Pada tahap ini berkaitan dengan pemrograman, instalasi, dan rencana pemeliharaan. Pada tahap ini juga dilakukan testing dan training dengan tujuan agar sistem dapat digunakan dengan sebaik-baiknya. 


\section{Penggunaan}

Langkah terakhir merupakan tahap dimana sistemyang dirancang telah siap untuk digunakan untuk karyawan.

\section{Hasil danPembahasan}

\section{Profil Perusahaan}

Distro Blacksheepberlokasi di Jln. Tgk Iskandar, Simpang Anoe - Lambhuk, Banda Aceh, bergerak dibidang penjualan berbagai macam pakaian, mulai dari kaos, kemeja, jaket, topi, tas, dan lain-lain. Distro Blacksheep memiliki 8 karyawan yang terdiri dari 1 bendahara, 1 kasir, 1 desainer, 3 marketing dan 2 di bagian gudang.

Distro Mensurfing beralamat di Jln. T. Iskandar Beurawe Kota Alam, Banda Aceh. memiliki 7 karyawan yang terdiri dari 1 orang bendahara, 2 orang kasir, 2 orang marketing, dan 2 di bagian gudang.

\section{Analisis Sistem dan Prosedur Secara Manual \\ Proses Persediaan Barang}

Setelah mengumpulkan data yang diinginkan melalui wawancara dan observasi dengan pemilik distro, sistem persediaan barang di dalam distro menerapkan tahap-tahap untuk menjual barang yang telah berjalan, yaitu:

1) Supplier mengirim barang kepada distro sesuai dengan apa yang telah dipesan.

2) Kasir menerima dan mengelola barang yang telah dikirim oleh Supplier

3) Kasir mencatat barang apa yang telah masuk ke distro

4) Gudang menerima barang yang telah dicatat kasir

5) Gudang menghitung barang yang telah masuk

6) Gudang menyerahkan catatan tentang jumlah barnag yang masuk kepada bendahara

7) Bendahara membuat laporan penjualan dari stok barnag yang ada

Bendahara menyerahkan laporan penjualan dan stok barang kepada pemilik distro.

\section{Diagram Konteks}

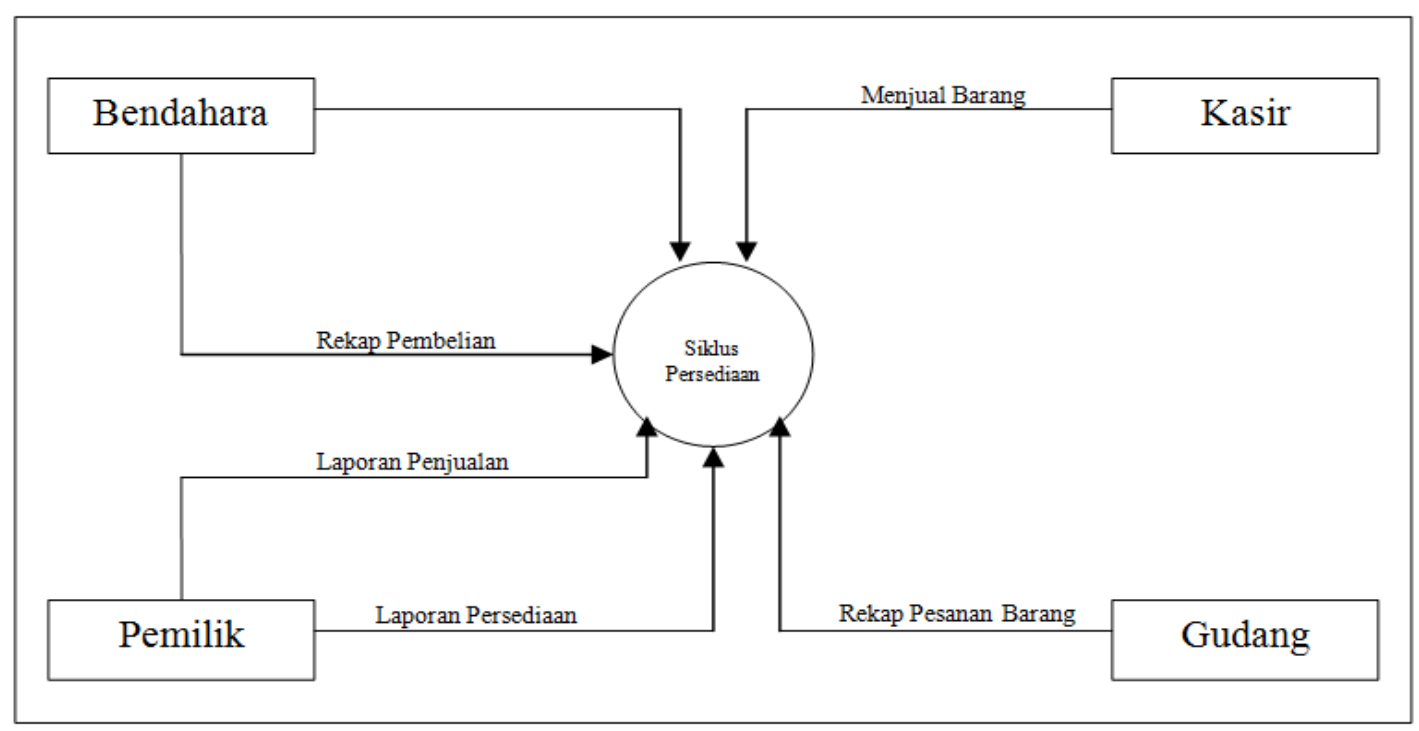




\section{Diagram Arus Data}

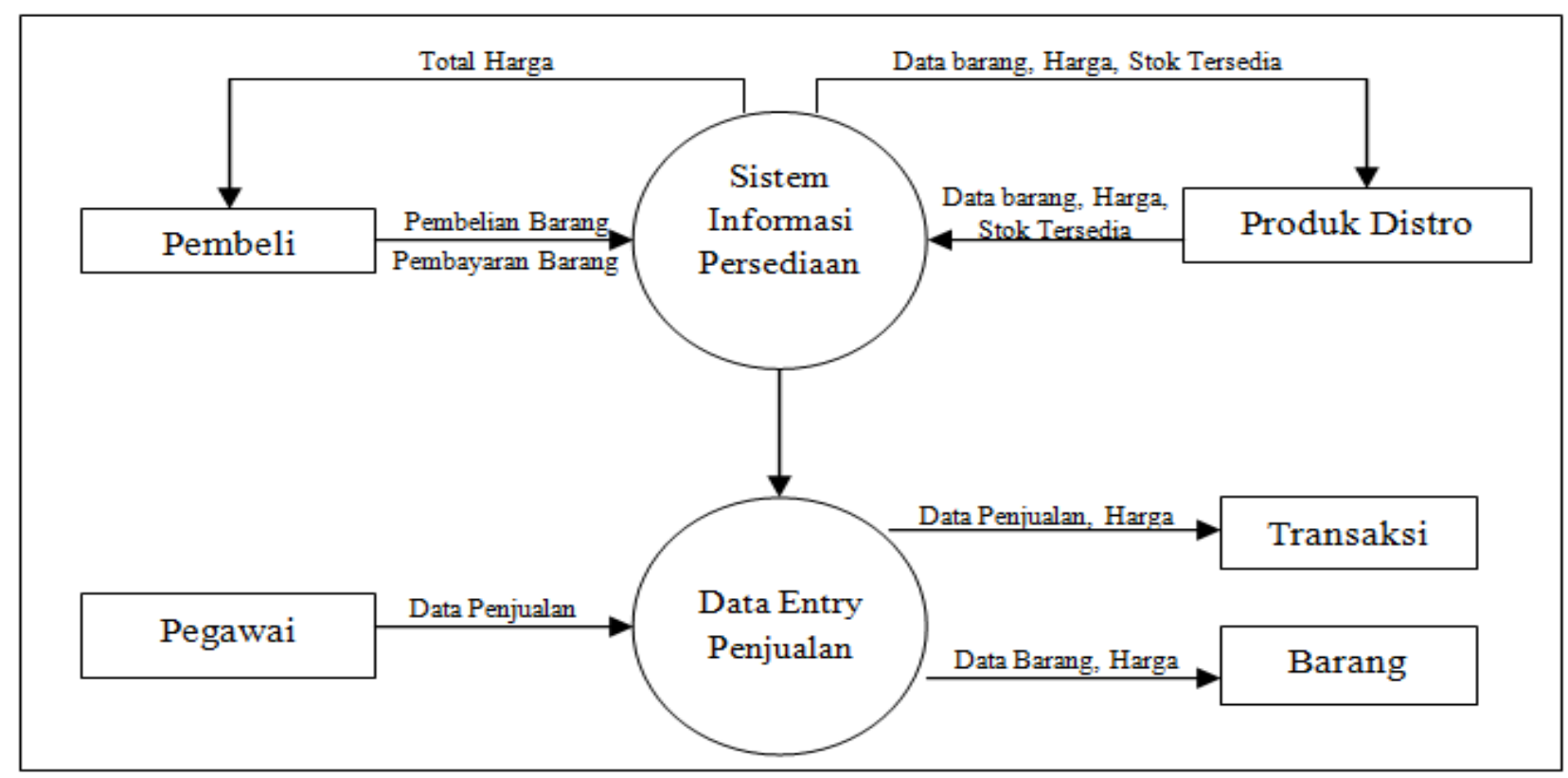

Evaluasi Sistem Berjalan

\begin{tabular}{|c|l|l|}
\hline NO & \multicolumn{1}{|c|}{ Permasalahan } & \multicolumn{1}{c|}{ Solusi/Rencana } \\
\hline 1 & $\begin{array}{l}\text { Proses penghitungan persediaan } \\
\text { barang masih sering mengalami } \\
\text { kesalahan }\end{array}$ & $\begin{array}{l}\text { Dengan menerapkan sistem infomasi } \\
\text { dapat mempermudah proses } \\
\text { penghitungan persediaan barng }\end{array}$ \\
\hline 2 & $\begin{array}{l}\text { Proses persediaan barang yang } \\
\text { tidak terkendali karena } \\
\text { pendataan dilakukan diakhir } \\
\text { bulan }\end{array}$ & $\begin{array}{l}\text { Dengan adanya sistem informasi } \\
\text { pendataan barang dapat dilakukan secara } \\
\text { langsung setiap ada transaksi yang terjadi }\end{array}$ \\
\hline 3 & $\begin{array}{l}\text { Keamanan data masih belum } \\
\text { terjamin jika ingin dikelola }\end{array}$ & $\begin{array}{l}\text { Adanya sistem sistem informasi } \\
\text { menjamin keamanan data yang ada } \\
\text { menjadi lebih baik. }\end{array}$ \\
\hline 3 & $\begin{array}{l}\text { Laporan akhir tidak akurat } \\
\text { karena kesalahan yang } \\
\text { dilakukan karyawan }\end{array}$ & $\begin{array}{l}\text { Dengan diterapkannya sistem informasi } \\
\text { laporan akhir penjualan bias dilihat } \\
\text { secara akurat }\end{array}$ \\
\hline
\end{tabular}

\section{Analisis Kebutuhan Sistem Informasi Usulan}

Berdasarkan hasil analisis dari sistem yang sedang berjalan yang telah dilakukan dan melihat permasalahan apa saja yang terjadi pada dsitro Blacksheep dan Menssurfing, maka perlu dilakukan pemecahan permasalahan yang terjadi dengan merancang sistem informasi menggunakan Microsoft Access pada sistem persediaan distro Blacksheep dan Menssurfing. Suatu sistem yang dapat memudahakan pengguna dalam melakukan pencatatan barang dan menghasilkan laporan akhir.

\section{Analisis Data}

Pada distro Blacksheep dan Mensurfing memiliki maslah dalam pencatatan persediaan barang karena masih menggunakan pencatatan secara manual. Pencatatan dan penyimpanan data yang dilakukan secara manual yang dilakukan dengan menggunakan 
buku atau kertas memiliki resiko seperti kehilangan atau kerusakan.

Disaat perushaan ingin melihat berapa jumlah barang yang tersedia di dalam gudang maka akan mendapat kesulitan karena harus melihat data satu persatu dan hal ini akan memakan waktu yang lama untuk mendapatkan dokumen yang diinginkan dikarenakan jumlah dokumen yang tidak sedikit, maka dari itu distro membutuhkan sebuah sistem yang dapat digunakan dengan mudah

\section{Analisis Penyimpanan Data}

Penyimpanan dokumen atau data pada distro yang digunakan saat ini berbentuk kertas-kertas yang dibentuk menjadi arsip. Penyimpanan data seperti itu membuat data sulit diakses sehingga memakan waktu yang cukup lama. Data yang disimpan juga tidak aman dalam segi keamanan dan perlu perhatian lebih agar tidak hilang atau rusak.

\section{Analisis Kebutuhan Sistem yang Diusulkan}

Dapat disimpulkan bahwa masalah yang telah dijelaskan diatas, maka distro Blacksheep dan Menssurfing membutuhkan suatu sistem informasi persediaan yang terkomputerisasi. Suatu sistem yang dapat digunakan dengan mudah bagi karyawan untuk menjalankan pekerjaan serta dapat menghemat waktu dan meminimalisir kesalahan yang terjadi. Sistem informasi meliputi hal-hal berikut:

1. Membutuhkan penyimpanan yang lebih baik dari sebelumnya agar pihak terkait dapat dengan mudah mengakses dengan cepat.

2. Suatu sistem yang dapat melakukan penghitungan secara otomatis terhadap persediaan barang yang ada.

3. Sistem yang membantu untuk mengetahui jumlah barang yang ada di dalam gudang untuk dijual kembali.

4. Sistem yang menghasilkan laporan akurat setiap terjadi transaksi.

5. Sistem yang dapat membuat laporan keuangan dari hasil penjualan barang yang ada.

\section{Perancangan Sistem}

Perancangan sistem pada distro Blacksheep dan Menssurfing memiliki tujuan sebagai berikut:

1. Untuk memenuhi kebutuhan pada perusahaan.
2. Untuk memberikan gambaran yang jelas dan lengkap pada pemrograman computer.

Setelah analisis pada sistem yang berjalan pada perusahaan dilakukan dan melihat masalah apa saja yang terjadi dalam sistem yang berjalan maka solusi yang dapat diberikan penulis adalah dengan merancang dan membuat sebuah sistem informasi yang terkomputerisasi untuk membantu perusahaan dalam mengelola sistem persediaan barang pada perusahaan.

\section{Diagram Konteks yang Diusulkan}

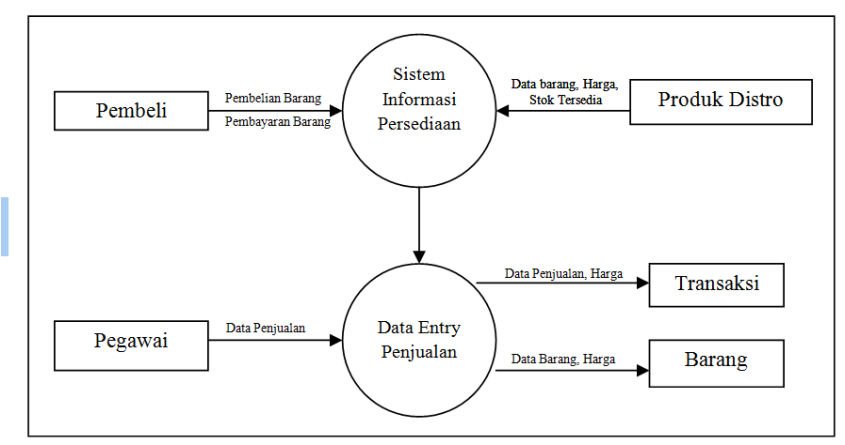

\section{Diagram Arus Data yang Diusulkan}

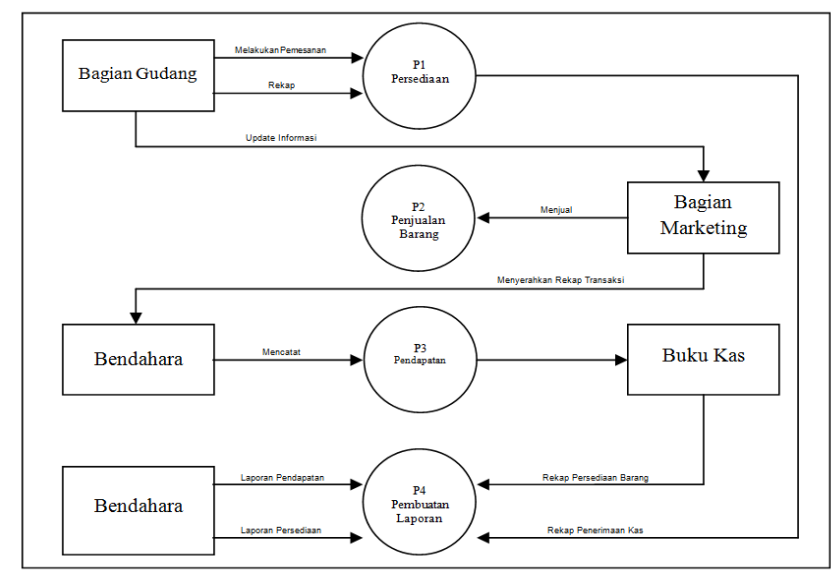

\section{Penggunaan Sistem}

Hasil pengujian yang telah dijalankan, dapat ditarik kesimpulan bahwa sistem persediaan yang dirancang berfungsi dengan baik pada distro Blacksheep dan Mensurfing. Sistem yang dirancang digunakan oleh user yang terlibat dalam keuangan atau yang diberikan password saja. Pengguna yang diberikan password untuk menggunakan aplikasi dipastikan tidak memberikan password kepada karyawan yang tidak memiliki tanggung jawab 
dibagian keuangan agar tidak terjadi manipulasi oleh karyawan lain.

Ketika sistem yang baru diterapkan seluruh karyawan dapat menerima sistem dan mengoperasikan sistem dengan baik, penerapan sistem pada distro Blacksheep dan Mensurfing sangat membantu jalannya aktifitas yang terjadi sehingga berdampak pada sistem pengendalian persediaan barang menjadi lebih baik, dimana proses pencatatan stok barang menjadi lebih efisien sehingga tidak ada terjadi kesalahan dalam pencatatan barang maupun kehilangan barang lagi.

Penerapan sistem informasi persediaan yang terkomputerisasi pada distro Blacksheep dan Mensurfing berjalan dengan lancar sehingga dapat menyesaikan masalah terkait kesalahaan pencatatan dan kehilangan yang pernah terjadi pada distro tersebut. Masalah mengenai keakuratan laporan yang pernah terjadi juga dapat teratasi dengan baik, sehingga pelaporan yang ada pada perusahaan menjadi lebih akurat dan dapat diakses secara realtime.

\section{Kesimpulan dan Saran \\ Kesimpulan}

Setelah melakukan penelitian dan menjalankan aplikasi pada distro Blacksheep dan Mensurfing, kesimpulan yang dapat ditarik yaitu:

1. Merancang sistem informasi akuntansi persediaan distro Blacksheep dan Mensurfing menghasilkan sistem informasi persediaan yang lebih baik untuk digunakan oleh pengguna.

2. Perancangan sistem informasi persediaan pada distro Blacksheep dan Mensurfing menghasilkan dua hal yaitu input yang merupakan data yang kita masukan berupa informasi barangdan output adalah laporanlaporan dari persediaan barang di gudang.

3. Perancangan sistem informasi persediaan barang dapat menghasilkan informasi yang lebih baik, akurat dan terpertcaya.

4. Perancangan sistem membuat hasil pencarian stok barang menjadi mudah, cepat, dan tidak memerlukan waktu yang lama sehingga data menjadi lebih mudah diakses karena tidak menggunakan metode manual lagi.

\section{Saran}

1. Sebaiknya distro Blacksheep dan Mensurfing mengadakan pelatihan untuk pengguna aplikasi agar aplikasi yang dirancang dapat dijalankan dengan baik tanpa ada kesalahan.

2. Distro Blacksheep dan Mensurfing sebaiknya melakukan pengawasan rutin terhadap penggunaan perangkat keras maupun lunak, sehingga jika ada kekurangan bias segera diatasi.

\section{Daftar Pustaka}

Agus Ristanto. (2009). Manajemen persediaan edisi 1. Yogyakarta: Graha Ilmu

Akbar, R. I. N., \& Dahlan, A. (2013). Pembuatan Sistem Informasi Penjualan Pada Ade Jaya Ponsel Dengan Menggunakan Visual Basic. Jurnal Ilmiah DASI, 14(4), 39-43. Retrieved from

http://ojs.amikom.ac.id/index.php/dasi/article/vi ew/172

Alexandri, Moh. Benny. 2009. Manajemen Keuangan Bisnis: Teori dan Soal. Bandung: Penerbit Alfabeta.

Anwar, F., \& Karamoy, H. (2014). Analisis Penerapan Metode Pencatatan Dan Penilaian Terhadap Persediaan Barang Menurut Psak No.14 Pada Pt. Tirta Investama Dc Manado. Jurnal EMBA, Volume 2(2), 1296-1305.

Astuti, P. D. (2013). Sistem Informasi Penjualan Obat Pada Apotek Jati Farma Arjosari. Indonesian Jurnal on Computer Science - Speed (IJCSS) 16 FTI UNSA Vol 10 No 1 - Mei 2013 Ijcss.Unsa.Ac.Id, 10(1), 142-147.

Azhar Susanto. 2013. Sistem Informasi Akuntansi. Bandung: Lingga Jaya.

Baramuli, F., \& Pengemanan S, S. (n.d.). Analisis sistem informasi akuntansi persediaan pada yamaha bima motor toli-toli, 3(3), 52-62.

Davis, Gordon B. 2013. Kerangka Dasar Sistem Informasi Manajemen. Palembang: Maxikom.

Dr. La Midjan dan Azhar Susanto, 2001, Sistem Informasi Akuntansi 1Edisi 8. Bandung: Lingga Jaya

Gantino, R. (2014). Jurnal Riset Akuntansi - Volume VI / No.2 / Oktober 201477 Perancangan Dan Implementasi Sistem Informasi Manajemen Pada Tpa Kecamatan Pulogadung, Vi(1). 
Hartono, Bambang. 2013. Sistem Informasi Manajemen Berbasis Komputer. Jakarta: Rineka Cipta.

Hashim, N. M. Z., \& Arifin, N. A. M. M. (2013). Laboratory Inventory System. International Journal of Science and Research, 2(8), 2319$7064 . \quad$ Retrieved from https://www.ijsr.net/archive/v2i8/MDIwMTMy $\mathrm{NDg}=. \mathrm{pdf}$

Jogiyanto, HM. 2009. Analisis dan Desain Sistem Informasi. Yogyakarta: Andi OFFSET.

Krismiaji. 2010. Sistem Informasi Akuntasi. Edisi Ketiga. Yogyakarta: UPP STIM YKPN.

Kristanto, Andi. 2008. Perancangan Sistem Informasi dan Aplikasinya. Edisi Revisi. Cet. 1. Yogyakarta: Gava Media.

Ladjamudin, Al-Bahra Bin. 2013. Analisis dan Desain Sistem Informasi. Yogyakarta: Graha Ilmu.

Laudon, Kenneth C., dan Jane P. Laudon, (2012). Management System: Managing the Digital Firm Twelfth Edition. New Jersey: Prentice Hall.

Manengkey, N. (2014). Analisis Sistem Pengendalian Intern Persediaan Barang Dagang Dan Penerapan Akuntansi Pada Pt. Cahaya Mitra Alkes. Natasya Manengkey. Analisis Sistem Pengendalian... Jurnal EMBA, 132(3), 13-21.

Munawaroh, S. (2006). Perancangan Sistem Informasi Persediaan Barang. Jurnal Teknologi Informasi DINAMIK, XI(2), 124-133.

PSAK 14. (2008). Dewan Standar Akuntansi Keuangan.

Romney Marshall and Steinbart, 2012, Accounting Information System (12th Edition). London: Prentice Hall.

Romney, Marshal B., dan Steinbart, Paul John. 2012. Accounting Information Systems. USA: Cengage Learning.

Satzinger, Jackson, Burd. 2010. "System Analisis and Design with the Unified Process". USA: Course Technology, Cengage Learning.

Sekaran, Uma. 2009. Research Methods for Business : Metodologi Penelitian untuk Bisnis. Edisi 4.Buku 1. Jakarta: Salemba 4

Sutabri, Tata. 2012. Analisis Sistem Informasi. Yogyakarta: Andi.

Sutarman. 2009. Pengantar teknologi Informasi. Jakarta : Bumi Aksara.
Sutarman. 2012. "Buku Pengantar Teknologi Informasi”. Jakarta: Bumi Aksara

Sugiyono. 2010. Metode Penelitian Pendidikan Pendekatan Kuantitatif, kualitatif, dan $R \& D$. Bandung: Alfabeta

Sugiyono, 2012.Metode Penelitian Kombinasi (Mixed Methods). Bandung : Alfabet

Sugiyono. 2014. Metode Penelitian Pendidikan Pendekatan Kuantitatif, Kualitatif Dan $R \& D$. Bandung: Alfabeta.

S Warren, C., M Reeve, J., E Duchac, J., Suhardianto, N., Sulistyo Kalanjati, D., Abadi Jusuf, A., \& D Djakman, C. (2014). Pengantar Akuntansi Adaptasi Indonesia (25th ed.). Jakarta: Salemba Empat.

Tamodia, W. (2013). Evaluasi Penerapan Sistem Pengendalian Intern Untuk Persediaan Barang Dagangan Pada Pt. Laris Manis Utama Cabang Manado. Jurnal EMBA, 1(3), 20-29.

Wibowo, R. A. (2009). Sistem Informasi Persediaan Keluar Masuk Barang Pada Inside Distro Jakarta. Spead, 1(4), 19-24.

Wulandari, T. Y., \& Nugroho, G. K. (2012). Sistem Komputerisasi Penggajian Guru Pada Sekolah Menengah Pertama 2 Sambungmacan. Journal Speed - Sentra Penelitian Engineering Dan Edukasi, 4(3), 45-50. 